\title{
症例報告（推薦論文）
}

推薦者：日本臨床免疫学会理事 田中良哉

進行性多巣性白質脳症をきたした全身性エリテマトーデスの一例

\author{
金 子 英 樹*1，駒野有希子*1,*2，渡 部 香 織*1，柏 森 高*3
} 高田和生 ${ }^{* 1}$, 南木 敏 宏*1,*2, 宮坂信 之*1

\section{A case of progressive multifocal leukoencephalopathy associated with systemic lupus erythematosus}

\author{
Hideki KAneKO*1, Yukiko Komano*1,*2, Kaori Watanabe*1, Kou KaYAmori*3, \\ Kazuki TAKADA*1, Toshihiro NANKI*1,*2 and Nobuyuki MIYASAKA*1 \\ ${ }^{*}$ Department of Medicine and Rheumatology, Tokyo Medical and Dental University, \\ ${ }^{*}$ Department of Pharmacovigilance, Tokyo Medical and Dental University, \\ ${ }^{*}$ Division of Surgical Pathology, Tokyo Medical and Dental University Hospital
}

(Received September 24, 2008)

\begin{abstract}
summary
We describe a case of systemic lupus erythematosus (SLE) complicated with multifocal leukoencephalopathy (PML). A 57-year old woman, who had a five-year history of SLE, was admitted to our hospital because of fever and multiple subcutaneous nodules. Diagnosis of disseminated cryptococcosis was made based on histological and bacteriological examinations, and she was successfully treated with anti-fungal drugs. Corticoteroids were increased for persistent lupus activities. One month later, however, she gradually developed disorientation and short-term memory loss. A brain magnetic resonance image (MRI) showed a focal lesion in the white matter of the right frontal lobe. Brain biopsy demonstrated demyelinating lesions with the presence of JC viral antigen. Polymerase chain reaction also revealed JC virus DNA in the cerebrospinal fluid. Her condition gradually progressed, and she died a year later due to pneumonia. Although acquired immunodeficiency syndrome is currently the most common disease associated with PML, patients with autoimmune diseases receiving immunosuppressive therapy also have risks for developing PML. In patients with SLE presenting with subacute neurological abnormalities and white matter lesions in the brain, PML should be considered in the differential diagnosis.
\end{abstract}

Key words_ progressive multifocal leukoencephalopathy, systemic lupus erythematosus

抄 録

全身性エリテマトーデス（SLE）の経過中に進行性多巣性白質脳症（PML）を発症した 1 例を経験したので報 告する. 症例は 57 歳女性. 2000 年 SLE と診断され， 2004 年よりメチルプレドニゾロン $16 \mathrm{mg} /$ 日を投与されてい た. 2005 年 9 月, 発熱, 顔面・四肢の紅斑を生じ, 当科紹介入院. 播種性クリプトコッカス症と診断し，抗真菌 薬の投与により軽快した。その後，多関節炎，四肢紅斑，低補体血症などSLEの再燃を認めたため，11月下旬よ りプレドニゾロン $40 \mathrm{mg} /$ 日に増量された。12 月末より，失見当識，記銘力低下を生じ，脳 MRIにて右前頭葉皮 質下白質に占拠性病変を認めた。開頭脳生検による脳病理組織所見及び PCR 法にて脳春髄液中の JCウイルス DNA 陽性を認めたことから PML と診断したＰML は中枢神経系に脱髄病変をきたす致死的病態であり，AIDS 患者に抢ける日和見感染症として知られている. 自己免疫疾患患者に掞いても免疫抑制薬や生物学製剂使用に関連 して，PMLを発症することが注目されている．SLEの経過中，亜急性の中枢神経障害，脳白質病変を認めた場合 にはPML を鑑別診断としてあげる必要があり，文献的考察を含めて報告する.

\section{I. はじめに}

*1東京医科歯科大学大学院医歯学総合研究科膠原病 .

リウマチ内科学

*2同上, 薬害監視学

*3東京医科歯科大学医学部付属病院病理部
進行性多巣性白質脳症 progressive multifocal leukoencephalopathy（以下，PML）はJCウイルスに よる中枢神経系遅発性ウイルス感染症である。human immunodeficiency virus (HIV) 感染の流行に伴 
い, HIV 感染者の約 5\%に認められる日和見感染症 として知られるようになった ${ }^{1)}$. 本症は, 発症後数 ケ月から 1 年で死亡する致死的感染症である. 今 回，全身性エリテマトーデス（SLE）の経過中に見 当識障害を来し，開頭脳生検で PML と診断した一 例を経験したので，文献的考察を加え報告する。

\section{II. 症例}

症 例 : 57 歳, 女性

主 訴: 発熱, 皮疹

現病歴: 2000 年 5 月, 蝶形紅斑, 多関節炎, 白 血球減少，抗 DNA 抗体陽性より近医にて SLE と 診断され，プレドニゾロン（PSL） $60 \mathrm{mg} /$ 日，シク ロホスファミド $50 \mathrm{mg} /$ 日にて加療開始された。 2002 年 8 月, クリプトコッカス肺炎・髄膜炎を発 症し，抗真菌薬にて軽快した。 2004 年 10 月，SLE が再燃（多関節炎，低補体血症，抗 dsDNA 抗体上 昇）し，以後当科入院までメチルプレドニゾロン （mPSL） $16 \mathrm{mg} /$ 日を投与された。2005 年 7 月よ り, 微熱, 顔面・四肢の紅斑, 皮下硬結が出現し,

9 月には胸部単純レントゲン像で両側上肺野に斑状 影を認めたため, 精査加療目的に 9 月 7 日当科紹介 入院となった.

生活歴 : 自宅ベランダで鳩との接触歴あり

家族歴 : 特記すべきことなし

合併症 : B 型肝炎キャリア

入院時現症：身長 $153.4 \mathrm{~cm}$, 体重 $46.7 \mathrm{~kg}$. 意識 清明, 体温 $37.4^{\circ} \mathrm{C}$, 血圧 $134 / 78 \mathrm{mmHg}$, 脈拍 $90 /$ 分 - 整, 顔面と頚部に浸潤性紅斑, 両手指に爪囲紅 斑，凍瘡様皮疹，指尖梗塞を認めた。また，四肢体 幹に赤色，圧痛，排膿を伴う皮下結節が多発してい た。胸腹部に異常所見なし，右肘関節，左膝関節に 腫脹・圧痛㐫り。

入院時検査所見（表 1）: 白血球減少，リンパ球 減少, 正球性正色素性貧血, 血小板減少, 肝胆道系 酵素上昇, $\mathrm{CRP}$ 高值, 赤沈六進を認めた。血清学 的には高ガンマグロブリン血症, 低補体血症, 免疫 複合体, 抗 DNA 拈よび抗 Sm 抗体高值を認めた.

入院時画像所見：胸部単純レントゲン像および胸 部 CT 像で，両側上肺野，左中肺野に多発結節影を 認めた.

入院後経過（図 1）：入院翌日, 肺の結節性病変 に対して, 経気管支肺生検を行ったところ, 病理組 織標本でクリプトコッカス菌体が認められた。皮下 結節の病理検体からもクリプトコッカスが同定され
表 1 入院時検査所見

\begin{tabular}{|c|c|c|}
\hline ［検尿］ & 異常なし & [血算］ \\
\hline [血清 $]$ & & $2368 \mathrm{mg} / \mathrm{dl}$ \\
\hline WBC & $3600 / \mu 1$ & $166 \mathrm{mg} / \mathrm{dl}$ \\
\hline $\mathrm{Neu}$ & $93 \%$ & $398 \mathrm{mg} / \mathrm{dl}$ \\
\hline Lym & $3 \%$ & $\mathrm{CH} 50$ \\
\hline Mo & $4 \%$ & $42 \mathrm{mg} / \mathrm{dl}$ \\
\hline $\mathrm{RBC}$ & 338 万 $/ \mu 1$ & $3 \mathrm{mg} / \mathrm{dl}$ \\
\hline $\mathrm{Hb}$ & $9.6 \mathrm{~g} / \mathrm{dl}$ & $22.7 \mu / \mathrm{ml}$ \\
\hline Plt & 12.2 万 $/ \mu 1$ & 抗核抗体 1280 倍 (均一型) \\
\hline [血沈］ & $118 \mathrm{~mm} / \mathrm{h}$ & 抗 ds-DNA 抗体 $\quad 191 \mathrm{IU} / 1$ \\
\hline [生化学] & & 抗 ss-DNA 抗体 \\
\hline $\mathrm{TP}$ & $5.6 \mathrm{~g} / \mathrm{dl}$ & 抗 $\mathrm{Sm}$ 抗体 $\quad 99.6 \mathrm{U} / \mathrm{ml}$ \\
\hline Alb & $2.6 \mathrm{~g} / \mathrm{dl}$ & 抗カルジオリピン IgG 抗体 \\
\hline BUN & $16 \mathrm{mg} / \mathrm{dl}$ & $11 \mathrm{U} / \mathrm{ml}$ \\
\hline Cre & $0.5 \mathrm{mg} / \mathrm{dl}$ & ループスアンチコアグラント \\
\hline $\mathrm{LDH}$ & $321 \mathrm{U} / 1$ & 陰性 \\
\hline AST & $100 \mathrm{U} / 1$ & ハプトグロビン \\
\hline ALT & $82 \mathrm{U} / 1$ & 直接クームス \\
\hline$\gamma$-GTP & $478 \mathrm{U} / 1$ & 間接クームス \\
\hline Glu & $136 \mathrm{mg} / \mathrm{dl}$ & [感染症 $]$ \\
\hline \multirow[t]{2}{*}{ CRP } & $2.2 \mathrm{mg} / \mathrm{dl}$ & $\beta-\mathrm{D}$ グルカン $\quad 14.7 \mathrm{pg} / \mathrm{ml}$ \\
\hline & & $\begin{array}{lr}\text { クリプトコッカス抗原 } & 8 \text { 倍 } \\
\text { アスペルギルス抗原 } & \text { 除性 }\end{array}$ \\
\hline
\end{tabular}

たため, 播種性クリプトコッカス感染症と診断し, ホスフルコナゾールの投与を開始した。 一方，入院 時より, 顔面紅斑, 指尖梗塞, 多関節炎, 低補体血 症, 抗 ds-DNA 抗体の上昇を認め, SLE の疾患活 動性は高いと考えられた。このため，クリプトコッ カス感染症の軽快を確認後, ホスフルコナゾールを 継続投与しながら 11 月 22 日より PSL $40 \mathrm{mg} /$ 日に 増量した。その後, 紅斑, 関節炎は軽快したが， 12 月末より徐々に情動不安定, 失見当識, 記銘力低下 が出現した。2006 年 1 月 10 日に施行された脳 MRI では右前頭葉皮質下白質に長径約 $5 \mathrm{~cm}$ の T1 強調像にて低信号, T2 強調画像と FLAIR 像にて 高信号を示す病変を認めた（図 $2 \mathrm{~A}, \mathrm{~B}, \mathrm{C}$ )。髄液所 見では蛋白 $(59 \mathrm{mg} / \mathrm{dl}), \operatorname{IgG}$ index $(0.85)$ の軽度 高值を認めたが, 細胞数正常, グラム染色・墨汁染 色・クリプトコッカス抗原は㓌性であった。 同時期 に上肢に皮下膿瘍が出現し, 膿および血液培養にて 2 度黄色ブドウ球菌が検出されたため, 同菌による 脳膿瘍の可能性を考えセフトリアキソンの投与を行 った。ただし，脳病変はガドリニウム造影 MRI で は, 造影効果に乏しく, ノカルジア㧍よびトキソプ ラズマ等による脳膿瘍の可能性も否定できなかった ため，ST 合剤の投与も行なった.

上記治療にも関わらず，2月 10 日全身痤攣を生 

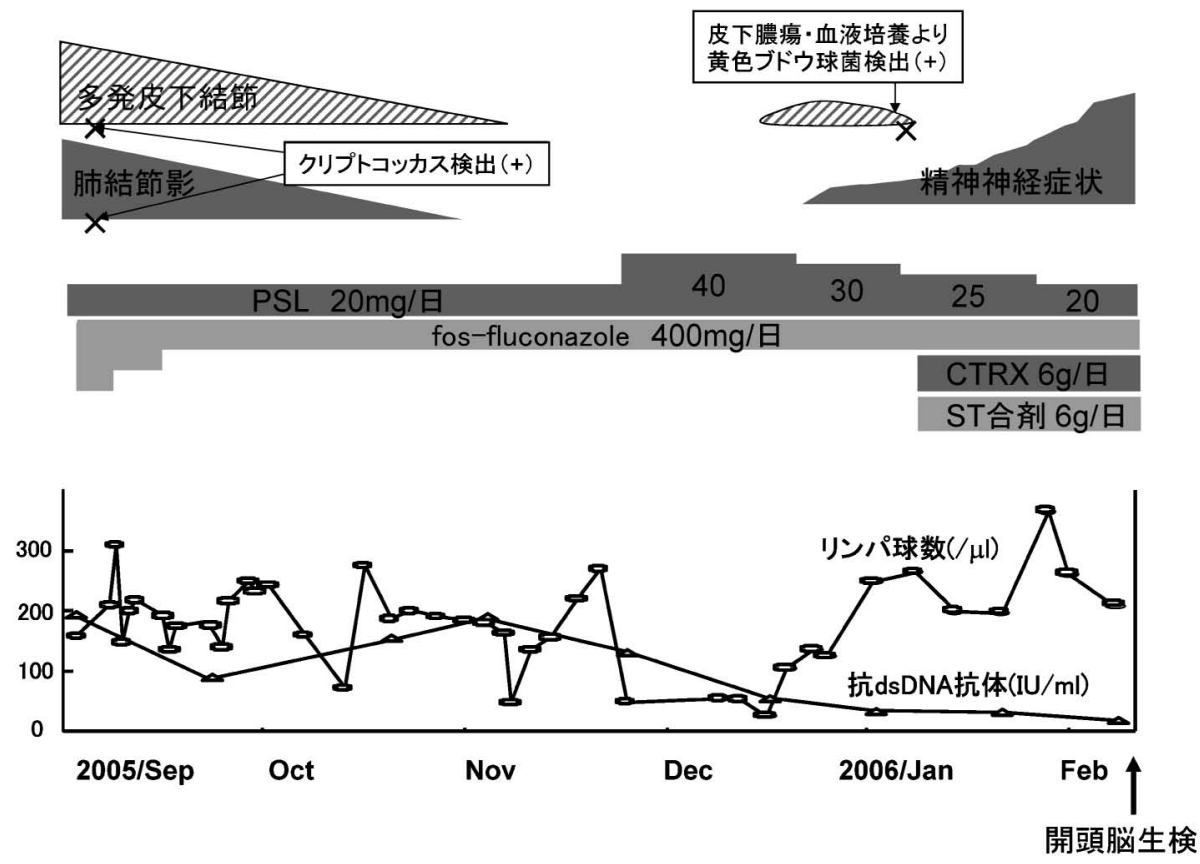

図 1 入院後経過

A

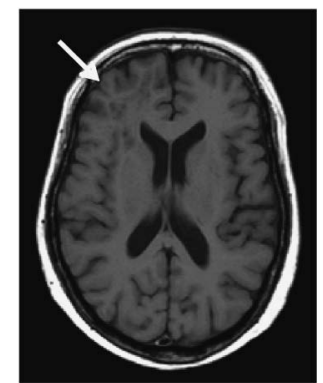

C

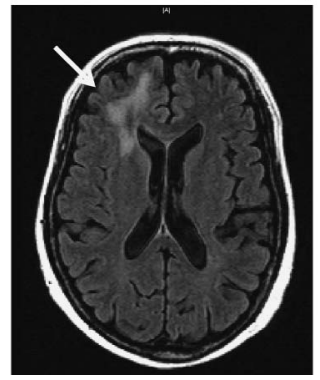

B

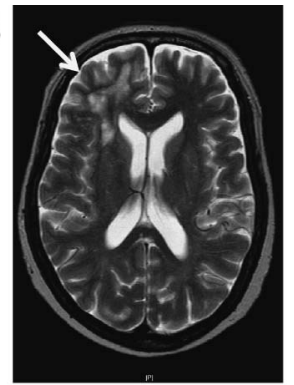

$\mathrm{D}$

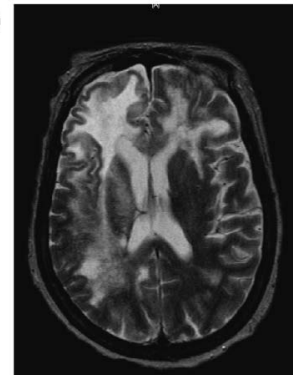

図 2 脳 MRI 所見

2006 年 1 月 10 日脳 MRI T 1 強調画像 (A)，T2 強調 画像 (B), FLAIR 像 (C), 2006 年 4 月 26 日 T2 強調 画像 $(\mathrm{D})$. 病変部位 (矢印).

じ，MRI 上では脳病変は左前頭葉まで拡大してお り，抗菌剂による治療は無効と考えられた。このた め, 2 月 15 日開頭脳生検施行したところ, 前頭葉 皮質下白質の病理組織にて皮質・白質境界部に泡沫 状のマクロファージの集簇巣を認め，その中に bizarre な核々好酸性の豊かな胞体を有するグリア 細胞が散見された．また，マクロファージの集簇巣 周囲には腫大した hyperchromatic な核を有するグ リア細胞を認めた（図 3A）。さらに，JCウィルス
A

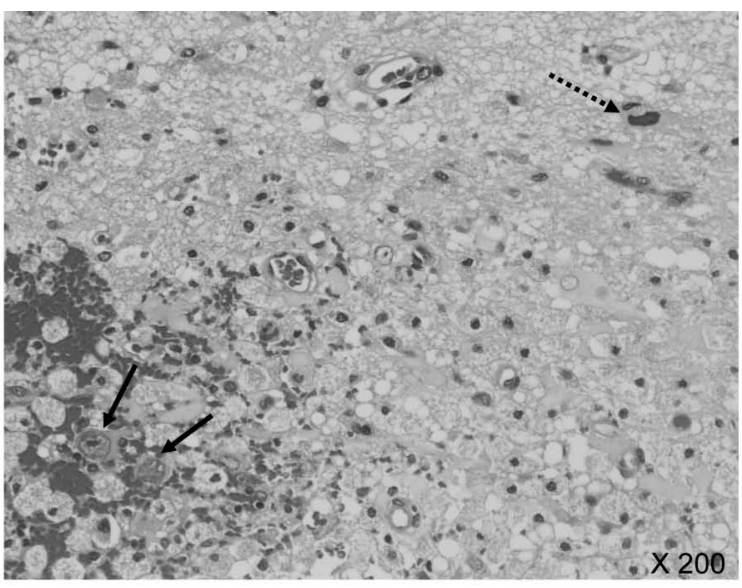

B

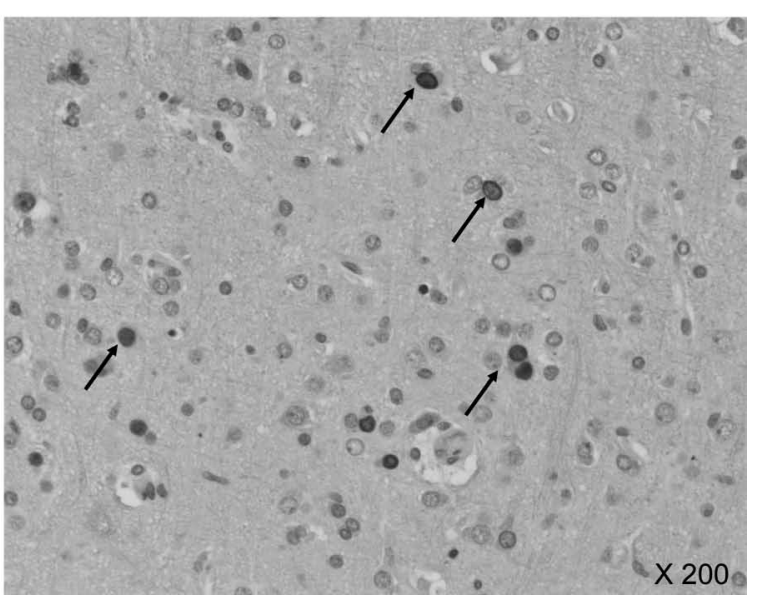

図 3 脳病理組織所見

前頭葉皮質下白質の病理組織 HE 染色所見 (A). bizarre な核と好酸性の豊かな胞体を有するグリア細胞 (実線矢印), および腫大した hyperchromatic な核を持つグリア細胞を認 めた（点矢印）.JCウィルスのカプシド蛋白である VP2/ VP3 に対する抗体を用いた免疫組織染色（B).グリア細胞 の核に陽性所見を認める (矢印). 
のカプシド蛋白である VP2/VP3 に対する抗体を用 いた免疫組織染色では,グリア細胞の核に陽性所見 を認め（図 3B），術前に採取した髄液を用いた PCR 法においてJCウイルス核酸が陽性と判明し たため, PML と診断した。抗ウイルス薬は, 重篤 な副作用が生じうること，既に広範な脳病変を認め ていること, 生命予後の改善については確立してい ないため使用しなかった。PSL は徐々に減量し 15 $\mathrm{mg} /$ 日とした。 1 ヶ月後, 半昏睡となり，4月 26 日 の MRI では右側頭から後頭葉にまで病変の拡大を 認めた（図 2D）。発症約 14 ヶ月後, 他院にて肺炎 を合併し死亡した。

\section{III. 考察}

PML は，亜急性進行性の中枢神経障害をきた し, 記憶障害などの高次機能障害, 構語障害, 脳神 経障害, 片麻㽻, 運動失調など多彩な神経症状を呈 し，数ヶ月で無動性無言症の状態に抢ちいる極めて 予後不良な疾患である.

PML の病原体である JCウイルスは, 8 割以上 のヒトに無症候性感染しており, リンパ組織, 脾 蔵, 骨髄, 腎臓に潜伏感染している ${ }^{2}$. 細胞性免疫 の低下により再活性化されると，JCウイルスに感 染したリンパ球を介して脳へ伝播し，グリア系細胞 に感染する ${ }^{3)}$ ささらに，髄鞘を形成するオリゴデン ドログリアへ JCウイルスが感染することにより， 脱髄病変が生じると推測されている.

PMLの基礎疾患として，かつては血液疾患が大 半を占めていたが，現在では PML 患者の 8 割以上 が HIV 感染者である ${ }^{4)}$. 一方で, 担癌患者, 臓器 移植のレシピエントにおける報告や, 生物学的製剂 であるナタリズマブ（抗 $\alpha 4$ インテグリン抗体）投 与中の多発性硬化症抒よびクローン病患者に抢ける 発症も報告されている ${ }^{5,6)}$. 最近では, リツキシマ ブ（抗 CD20 抗体）投与を受けた SLE 患者 2 名が PML を合併したことから，米国食品医薬品局 （FDA）から注意勧告が行なわれた7,8).

PML を合併したSLEの症例は, 我々が検索しえ た限り本症例を含めて 27 例報告されている (表 2) ${ }^{7 \sim 10)}$. 治療薬について記載のあった 24 例中 12 例に免疫抑制薬が投与されていた. ステロイド 薬は，24 例中 15 例に使用されていたが，投与量は PSL 0〜 40 mg/日と様々であった.PML 発症時の 神経症状は, 構語障害, 脳神経障害, 片麻痺, 運動 失調, けいれんなどが認められた。病巣は大脳・小
表 2 PML を合併した SLE 患者の臨床的特徵(本症例を含む)

\begin{tabular}{ll}
\hline \hline 報告数 & 27 例 \\
\hline 平均年齢 & 44 歳 $(21 \sim 66)$ \\
\hline 性別 & 男性 3 例 女性 24 例 \\
\hline SLE の罹病期間 & 10 年 $(1 \sim 27)$ \\
\hline PML 発症時の免疫抑制 & 24 例中* アザチオプリン 3 \\
薬8 & シクロホスファミド 3 \\
& リツキシマブ 2 \\
& アザチオプリン \\
& +シクロスポリン 1 \\
& レフルノミド 1 \\
& クロラムブシル 1 \\
& メトトレキサート 1 \\
\hline
\end{tabular}

PML 発症時の神経症状 22 例中* 高次機能障害 6

構語障害 10

脳神経障害 3

片麻痺 10

運動失調 9

けいれん 2

$\begin{array}{lr}\text { 病変部位 (PML 診断時の } 20 \text { 例中* } & \text { 大脳 } 11 \\ \text { MRI 所見) } & \text { 小脳 } 9 \\ & \text { 細幹 } 6\end{array}$

中枢神経ループスと混同さ 15 例 れた例

\begin{tabular}{ll}
\hline 抗ウイルス薬投与 & 有り 14 例 \\
& シドフォビル 6 \\
& シタラビン 3 \\
& インターフェロン 5 \\
\hline 転帰 & 死亡 22 例 \\
& 不明 3 例 \\
& 21 ヶ月後まで経過観察 1 例 \\
& 4 年後まで経過観察 1 例 \\
\hline \&PML 発症半年以内に使用されていた免疫抑制薬 \\
* 記載のあった症例数
\end{tabular}

脳・脳幹のいずれか，または大脳と小脳，小脑と脳 幹にわたって認められた．特記すべき点として， PML の診断に至るまでに, 中枢神経ループスと診 断された症例が 15 例あり, そのうち 8 例はステロ イド薬および免疫抑制薬の投与が行なわれ, 神経症 状の増悪が認められた. PMLに対し抗ウイルス薬 の投与を受けた 14 例中 5 例は神経後遺症を残して 改善したものの，5例中 3 例に関する転帰は不明で ある. 残り 2 例は, 4 年および 21 ヶ月後まで経過 観察された。 27 例中 22 例は死亡が確認され, PML 診断後の生存期間は平均 7.6 ヶ月であった.

PML の診断は, 病理組織学的に脳脱䯣病変にお いて JCウイルス抗原を検出することで確定され る. また, 臨床経過と画像所見から PML が疑われ 
る症例において，髄液中の JCウイルス DNA が検 出されれば PML と診断される11). 画像診断として 最も有用なのは，MRI である，病変部位は $\mathrm{T} 1$ 強調 像にて低信号, T2 強調像にて高信号を示し,

FLAIR 像では脱髄病変が明瞭に高信号で描出され る. また, 造影効果に乏しく, mass effect を欠くこ とが特徵的である12).

本症例は, 進行性の中枢神経障害, 画像所見で PML に特徵的な脳白質病変, 脳生検にて JCウイ ルス抗原陽性の脱髄病巣を認めたこと, 髄液中の JCウイルス DNA が陽性であったことから PML と診断した。本症例は, SLE 発症時に PSL60 mg/ 日抢よびシクロホスファミド $50 \mathrm{mg} /$ 日で治療が開 始され，約 2 年後にクリプトコッカス肺炎抢よび䯣 膜炎を発症していることから，当時より免疫抑制状 態が遷延していたと推測される，さらに，PML 発 症の約半年前には, 播種性クリプトコッカス感染症 を認めていたことから，顕著な免疫抑制状態を背景 にPML を発症したものと推測される.

HIV 感染者に生じた PML に対しては, highly active antiretroviral therapy（HAART）療法により 免疫能を賦活化することにより，有意な延命が期待 できる、また，HAART 療法に，シタラビン，シ ドフォビル, インターフェロン $\alpha$, ビダラビン, ア シクロビル，などの抗ウイルス薬を併用した臨床研 究が行われている13)。本症例のように非 HIV 感染 患者に発症したPML に対しては, PML 発症の誘 因となった免疫抑制療法の中止が原則であり, 抗ウ イルス薬の有効性は確立していない14).

\section{IV. 結 論}

SLE の経過中にPML を合併した一症例を経験し た.PML は稀な中枢神経感染症であるが，極めて 予後不良な病態である。したがって, SLEの経過 中に亜急性の中枢神経障害, 脳白質病変を認めた場 合には PML 鑑別すべき疾患として考慮し早期診 断に努める必要がある.

謝 辞 : JCウィルスの免疫染色を施行頂いた杏 林大学医学部病理学教室の先生方に, 深謝申し上げ ます。

\section{文献}

1) Berger JR, et al.: Progressive multifocal leukoencephalopathy associated with human im- munodeficiency virus infection. A review of the literature with a report of sixteen cases. Ann Intern Med 107: 78-87, 1987.

2) Seth P, et al.: Advances in the biology of JC virus and induction of progressive multifocal leukoencephalopathy. J Neurovirol 9: 236-246, 2003.

3) Sabath BF, et al.: Traffic of JC virus from sites of initial infection to the brain: the path to progressive multifocal leukoencephalopathy. $J$ Infect Dis 186 (Suppl 2): S180-186, 2002.

4) Eng PM, et al.: Characteristics and antecedents of progressive multifocal leukoencephalopathy in an insured population. Neurology 67: 884886, 2006.

5) Hou J, et al.: Progressive multifocal leukoencephalopathy: JC virus induced demyelination in the immune compromised host. J Neurovirol 6 (Suppl 2): S98-S100, 2000.

6) Langer-Gould A, et al. Progressive multifocal leukoencephalopathy in a patient treated with natalizumab. N Engl J Med 353: 375-381, 2005.

7) Harris HE. Progressive multifocal leucoencephalopathy in a patient with systemic lupus erythematosus treated with rituximab. Rheumatology (Oxford) 47: 224-225, 2008.

8) http://www.fda.gov/medwatch/safety/2007/ feb07.htm.

9) Calabrese LH, et al.: Progressive multifocal leukoencephalopathy in rheumatic diseases: evolving clinical and pathologic patterns of disease. Arthritis Rheum 56: 2116-2128, 2007.

10) Ohta $K$, et al.: Lesion extension detected by diffusion-weighted magnetic resonance imaging in progressive multifocal leukoencephalopathy. J Neurol 248: 809-811, 2001.

11) Koralnik IJ, et al.: JC virus DNA load in patients with and without progressive multifocal leukoencephalopathy. Neurology 52: 253260, 1999.

12) Whiteman ML, et al.: Progressive multifocal leukoencephalopathy in $47 \mathrm{HIV}$-seropositive patients: neuroimaging with clinical and pathologic correlation. Radiology 187: 233-240, 1993.

13) De Luca A, et al.: Cidofovir added to HAART improves virological and clinical outcome in AIDS-associated progressive multifocal leukoencephalopathy. AIDS 14: F117-121, 2000.

14) Aksamit AJ.: Treatment of non-AIDS progressive multifocal leukoencephalopathy with cytosine arabinoside. J Neurovirol 7: 386-390, 2001. 